\title{
REKAYASA ULANG (REENGINEERING) SISTEM INFORMASI MANAJEMEN PERTANAHAN NASIONAL DENGAN PENDEKATAN UNIFIED MODELLING LANGUAGE(UML) Wahyuni*
}

\begin{abstract}
The euality of decisions, including in land management, need sufficient, precise and accurate data and information. Land Information System at national level become strategic instruments in providing data and information of land, that nowadays not only needed to provide legal certainty of land ownership, but also to support decision making in land management in term of restructuring land tenure and ownership, land value arrangement, land use planning and arrangement, and permit/license related to land development. The existing Land Management Information System (SIMTANAS) was considered irrelevant with current needs. In its database organization, the existing SIMTANAS only account on land registration. Land information that considered as strategic information, such as restriction of land use and arrangement, and responsibilities related to land right and ownership have not been integrated into the system. Regarding this condition, reengineering of SIMTANAS is considered crucial. Reengineering can be implemented using model driven approach with Unified Modeling Language (UML). UML is able to model reengineering from organizational model, functional model, static model and dynamic model of SIMTANAS.
\end{abstract}

Keywords: Land Information System, Reengineering, UML

Intisari: Kualitas keputusan, termasuk di dalamnya keputusan-keputusan dalam manajemen pertanahan sangat memerlukan data dan informasi yanng memadai, tepat, dan akurat. Sistem Informasi Pertanahan Nasional menjadi intrumen strategis dalam penyediaan data dan informasi pertanahan yang dewasa ini tidak hanya untuk kepentingan jaminan kepastian hukum penguasaan dan pemilikan tanah, namun sudah harus mampu mendukung keputusan-keputusan manajemen pertanahan dalam hal penataan penguasaan dan pemilikan tanah (land tenure), pengaturan yang terkait dengan nilai tanah (land value), pengaturan dan perencanaan penggunaan dan pemanfatan ruang (land use), dan pengaturan perizinan yang terkait dengan kegiatan pembangunan di atas bidang tanah (land development). Sistem Informasi Manajemen Pertanahan Nasional atau disebut SIMTANAS yang sudah ada tidak relevan lagi dengan kebutuhan karena disamping penyusunan basis data hanya berdasarkan pendaftaran tanah, informasiinformasi strategis bidang tanah, berupa pengaturan apa yang boleh dan tidak boleh dilakukan (restriction) serta kewajibankewajiban yang melekat pada bidang tanah (servitude) atau disebut aspek responsibility belum terintegrasi didalamnya. Rekayasa ulang (reengineering) SIMTANAS menjadi urgen dilakukan. Rekayasa ulang dapat menggunaka pendekatan model driven menggunakan unified modelling language (UML) UML dapat memodelkan rekayasa ulang mulai dari model organisasional, fungsional, model statis maupun model dinamis SIMTANAS.

Kata kunci: Sistem Informasi Pertanahan, Rekayasa ulang, UML

\section{A. Pendahuluan}

Kualitas keputusan sangat ditentukan oleh kualitas informasi yang dijadikan dasar untuk membuat keputusan itu. Perkembangan teknologi informasi dewasa ini telah menawarkan sebuah

* Pengajar Sekolah Tinggi Pertanahan Nasional, email:wahyuniwidigdo@gmail.com sistem baru dalam pengambilan keputusan yang disebut sebagai sistem pengambilan keputusan (decision support system) yang dikelola dalam sebuah sistem informasi. Penggunaan teknologi informasi dalam suatu organisasi diharapkan dapat meningkatkan produktivitas, mempercepat proses, dan memberikan dukungan informasi kepada pihak manajemen untuk mengambil keputusan dalam 
bidang tertentu.

Sistem informasi adalah perpaduan sekumpulan elemen yang dipertemukan dengan maksud untuk mengidentifikasi informasi yang dibutuhkan dan memastikan bahwa strategi sistem informasi tersebut selaras dengan strategi bisnis. Sistem informasi mempunyai peran yang sangat penting dalam organisasi yaitu untuk mendukung strategi bisnis organisasi untuk memperoleh keunggulan kompetitif. Semua aspek kehidupan seperti pendidikan, perbankan, transportasi, perpajakan, pengelolaan energi, mitigasi bencana, pengelolaan dan pengembangan wilayah, dan lain-lain sangat memerlukan ketersediaan data dan informasi yang tepat dan akurat sebagai dasar pengambilan keputusannya. Demikian pula dalam hal mengelola sumberdaya agraria, tentunya pegambilan keputusan harus selalu didasarkan pada data dan informasi yang tepat.

Keberadaan sistem informasi pertanahan yang dapat menyediakan informasi-informasi yang dapat digunakan untuk mendukung manajemen pertanahan merupakan sebuah keniscayaan. Keputusan untuk menerapkan suatu kawasan menjadi lahan pertanian perkebunan berkelanjutan misalnya, tentu harus didasari oleh data kemampuan dan kesuburan tanah pada kawasan itu. Keputusan penataan ruang harus berdasarkan data dan informasi yang cukup mengenai kemampuan tanah pada kawasan tertentu, sehingga dapat diputuskan penggunaan dan pemanfaatan terbaik untuk wilayah tersebut. Pembangunan maupun pengembangan sistem informasi pertanahan harus mampu memodelkan hubungan antara manusia dengan tanah yang dikenal sebagai RRR (Rights, Restriction, and Responsibility). Hubungan manusia dengan tanah di dalam konteks pertanahan di Indonesia diwujudkan melalui penguasaan, pemilikan, penggunaan, dan pemanfatan tanah $\left(\mathrm{P}_{4} \mathrm{~T}\right)$.

Sesungguhnya memodelkan hubungan manusia dengan tanah yang sangat kompleks itu bukan sesuatu yang mudah. Untuk itu diperlukan pendekatan yang dapat menggambarkan kompleksitas hubungan manusia dengan tanah. Pendekatan yang banyak digunakan dan telah distandarkan secara internasional adalah pendekatan Model Driven menggunakan Unified Modelling Language(UML).

\section{B. Pendekatan Model Driven menggunakan UML}

Unified Modeling Language (UML) diciptakan oleh Grady Booch, Ivan Jacobson, dan James Rumbaough (1999) sebagai upaya untuk memberikan standar desain dan analisis pemodelan data berorientasi obyek. Pemodelan UML adalah pemodelan visual yang merupakan cara berpikir tentang persoalan menggunakan model-model yang mewakili kondisi dunia nyata (Sholiq 2006). UML terdiri dari beberapa elemen grafis yang dikombinasikan untuk membentuk sebuah model dengan berbagai sisi pandang.

Model adalah simplikasi realitas (Booch et al. 1999). Model juga merupakan representasi aspekaspek yang dianggap penting dalam satu sisi pandang dari realitas dan memandang sederhana aspek yang lain (Rumbough, et al. 2004). Model diwujudkan melalui 2 cara yaitu model secara semantik (vis a vis) dan model secara visual yang dinotasikan dengan simbol-simbol.

UML merupakan bahasa pemodelan yang menggabungkan tiga metode orientasi obyek yang telah ada sebelumnya, yaitu, OMT (Object Modeling Technique), dan OOSE (Object-Oriented Software Engineering). UML merupakan kesatuan dari ketiga pemodelan tersebut. UML dikeluarkan oleh OMG (Object Management Group, Inc) yaitu organisasi internasional yang dibentuk pada tahun 1989, terdiri dari perusahaan sistem informasi, software developer, dan para user sistem komputer. UML menyediakan beberapa diagram untuk memodelkan sebuah sistem dari berbagai sudut pandang.

Pemodelan UML dari sudut pandang sistem secara statis (static view) dapat digambarkan dalam beberapa diagram yaitu: 
1. Use Case Diagram

2. Class Diagram

3. Componen Diagram

4. Deployment Diagram

Use Case Diagram digunakan untuk menggambarkan penggunaan sistem oleh aktor. Aktor adalah para stake holder yang mempunyai kepentingan terhadap sistem atau software. Dalam diagram ini tidak dimodelkan bagaimana sistem menyediakan kebutuhan para aktor tetapi apa yang akan disediakan oleh sistem.

Class Diagram atau diagram kelas digunakan untuk memodelkan obyek dan kelas yang terlibat dalam penyediaan informasi sesuai yang akan dibangun.

Component Diagram menggambarkan struktur dan hubungan antar komponen piranti lunak, termasuk saling ketergantungannya (dependency). Komponen piranti lunak adalah modul berisi code, baik berisi source code maupun binary code, baik library maupun executable, baikyang muncul pada compile time, link time, maupun run time. Pada umumnya komponen terbentuk dari beberapa class dan/atau package, tapi dapat juga dari komponen-komponen yang lebih kecil. Komponen dapat juga berupa interface, yaitu kumpulan layanan yang disediakan sebuah komponen untuk komponen lain.

Deployment Diagram digunakan untuk memodelkan bagaimana sistem atau software di install, pada server maupun client serta bagaimana server melayani client. Deployment diagram juga menyajikan arsitektur hubungan server client.

Sudut pandang active atau behaviour view dari sistem yang dimodelkan dapat disajikan dalam diagram-diagram:

1. Activity Diagram

2. Statechart Diagram

3. Sequence Diagram

4. Collaboration Diagram

Activity Diagram atau diagram aktivitas digunakan untuk memodelkan alur sebuah prosedur sistem informasi. Diagram aktivitas ini juga banyak digunakan untuk memodelkan alur atau tahapan dalam prosedur sebuah sistem. Misalnya untuk memodelkan alur pendaftaran tanah, alur peralihan hak atas tanah, atau layanan-layanan yang lain misal alur permohonan KTP, alur perizinan, dan sebagainya

Pemodelan dengan diagram-diagram $U M L$ tersebut memerlukan notasi-notasi yang disebut artefak UML. Notasi-notasi dasar dalam UML adalah kelas (classes), atribut (attribut of class), role of class, asosiasi, dan multiplisitas. Kelas merupakan obyek atau entitas yang diperlukan dalam membentuk informasi, atribut mendeskripsikan identitas dari sebuah kelas entitas. Asosiasi menggambarkan hubungan antar kelas. Asosiasi direpresentasikan dalam UML dengan sebuah garis yang menghubungkan dua kelas dengan nama asosiasi di atasnya. Asosiasi jenis ini dinamakan asosiasi biner (binary association). Role atau peran masingmasing kelas ditunjukkan pada masing-masing ujung garis yang berhubungan langsung dengan kelas. Kardinalitas atau multiplisitas digambarkan di atas ujung garis yang terkoneksi dengan kelas. Sebuah asosiasi kadang-kadang juga mempunyai atribut dan operasi seperti kelas sehingga disebut sebagai kelas asosiasi (association class). Kelas asosiasi dinotasikan seperti kelas biasa yang ditambah dengan garis putus-putus (Twumasi 2009).

Hubungan asosiasi juga digunakan dalam hubungan antar kelas yang sifatnya hierarki. Hubungan super kelas atau parent class dengan kelas turunan atau child class disebut sebagai hubungan "is a" atau dikenal dengan generalisasi.

\section{Rekayasa Ulang Sistem Informasi Pertanahan Nasional (SIMTANAS) dengan Pendekatan Unified Modelling Language (UML)}

Pendekatan Model Driven menggunakan UML untuk memodelkan sistem kadaster yang menjadi 
inti dari sistem informasi pertanahan dikemukakan oleh Tuladhar. Menurut Tuladhar (2002) sistem informasi pertanahan sebuah negara dipengaruhi sistem kadastral yang berlaku. Pada tahun 1995 FIG mengeluarkan pernyataan mengenai hubungan sistem kadaster, sistem administrasi pertanahan, dan sistem informasi pertanahan. Menurut Steudler (2007);

A cadastre is the core or basis of a land administration system and is defined as a parcel based and up-to-date land information system containing a record of interests in land (e.g. rights, restrictions, and responsibilities).

Sistem kadaster merupakan inti ataupun dasar dari sistem administrasi pertanahan dan didefinisikan sebagai sistem informasi pertanahan berbasis bidang yang up-to date yang terdiri dari kepentingan-kepentingan manusia dengan tanah (hak-haknya, batasan apa yang boleh dan tidak boleh dilakukan di atas/dalam tanahnya, dan tanggung jawab terhadap tanahnya). Sistem kadaster sendiri merupakan sistem dengan berbagai aspekyang sangat kompleks. Aspek-aspek dalam sistem kadaster ini akan sangat berguna untuk memodelkan sistem informasi pertanahan.

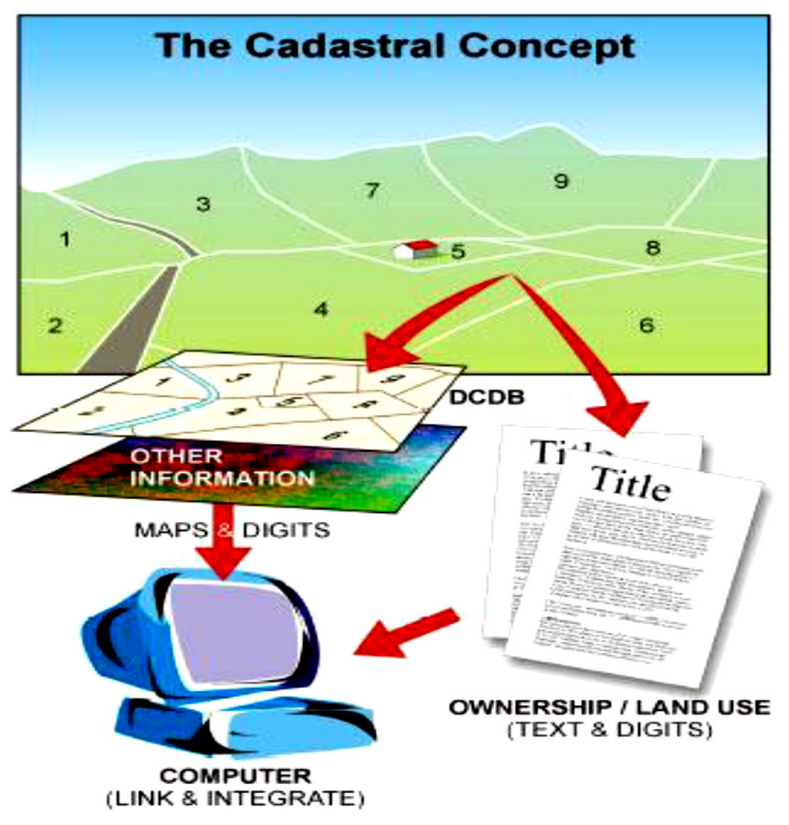

Gambar I. Pemodelan Sistem Kadaster dalam Sistem Informasi Pertanahan. (Sumber: FIG Statement on Cadastre, 1995)
Pemodelan sistem informasi pertanahan dapat disajikan dalam berbagai sudut pandang yaitu (1) model organisasional, (2) model fungsional, (3) model statis, dan (4) model dinamis (Tuladhar 2002). Pemodelan organisasional Pembangunan Sistem Informasi Pertanahan di Indonesia yang dikenal dengan SIMTANAS telah menjadi cita-cita sejak tahun 1970-an (Triyono 1992). Keputusan pembangunan SIMTANAS diangkat menjadi kebijakan nasional, pada era kepemimpinan Presiden Megawati Sukarno Putri dengan Keputusan Presiden Nomor 34 Tahun 2003 tentang Kebijaksanaan Nasional di Bidang Pertanahan. Pasal 1 huruf b, Keppres 34/2003 memerintahkan kepada Badan Pertanahan Nasional untuk membangun dan mengembangkan SIMTANAS. Untuk membangun SIMTANAS diperintahkan untuk melakukan (1) Penyusunan basis data tanahtanah aset negara/pemerintah/pemerintah daerah di seluruh Indonesia; (2) Penyiapan aplikasi data tekstual dan spasial dalam pelayanan pendaftaran tanah dan penyusunan basis data penguasaan dan pemilikan tanah, yang dihubungkan dengan e-government, e-commerce, dan e-payment; (3) Pemetaan kadastral dalam rangka inventarisasi dan registrasi penguasaan, pemilikan, penggunaan, dan pemanfaatan tanah $\left(\mathrm{P}_{4} \mathrm{~T}\right)$ dengan menggunakan teknologi citra satelit dan teknologi informasi untuk menunjang kebijakan pelaksanaan landreform dan pemberian hak atas tanah; (4) Pembangunan dan pengembangan pengelolaan penggunaan dan pemanfaatan tanah melalui sistem informasi geografi, dengan mengutamakan penetapan zona sawah beririgasi dan tanah-tanah produktiflainnya dalam rangka memelihara ketahanan pangan nasional.

Kebijakan ini terus dilanjutkan pada era Presiden Susilo Bambang Yudoyono dengan mengeluarkan Surat Edaran Menteri Sekretaris Negara perihal Arahan Presiden mengenai Permasalahan Pertanahan kepada Menteri Dalam Negeri, Menteri Keuangan, Menteri Kehutanan, Menteri BUMN, Kepala Badan Pertanahan Nasional, Gubernur dan 
Walikota se Indonesia. Presiden menginstruksikan untuk secara mandiri maupun bersama-sama membangun Bank Data Pertanahan dengan Mengembangkan SIMTANAS. Namun demikian kemauan politik ini tidak dapat terwujud secara konkrit oleh karena kentalnya egoisme sektoral. Perintah-perintah politik tersebut semestinya bisa diikuti dengan perencanaan matang mengenai pembangunan dan pengembangan SIMTANAS yang dilakukan lintas kementerian/sektor dan terdokumentasi dalam sebuah rencana pengembangan atau blue print SIMTANAS yang dideseminasikan secara lintas sektor. Perencanaan pembangunan SIMTANAS meliputi perencanaan visi, strategi pembangunan dan pengembangan, tujuannya, struktur yang akan dibangun termasuk peran dan fungsi dari kementerian terkait, serta peta jalan penbangunan serta pengembangannya. Fase perencanaan ini dapat menggunakan pemodelan organisasional SIMTANAS.

\section{Model Organisasional SIMTANAS}

Model organisasional memodelkan sistem secara keseluruhan mulai dari visi, tujuan dan strukturnya, rencana strategis dan rencana aksi. Artiya pemodelan sistem informasi pertanahan tidak hanya dilakukan dari sisi aplikasinya saja namun juga visi atau konsep sistem informasi pertanahan yang akan dibangun, tujuannya, strukturnya, rencana strategisnya, serta peta jalan untuk membangunnya. Konsep "fit for purpose land administration" (Enemark 2014), dapat menjadi dasar perumusan visi pembangunan dan pengembangan sistem informasi pertanahan masa sekarang. Sejarah perkembangan sistem informasi pertanahan sudah mengenal konsep sistem informasi pertanahan multiguna (Multi Purpose Land Information System) sejak tahun 1980-an (Williamson dan Ting dalam Enemark 2004). Namun demikian belum ada pendekatan strategis yang dapat dijadikan dalam pedoman dalam pembangunan SIP Multiguna itu. Pada awal pengembangan Land Office Computerisation (LOC) tahun 1997, sebagai tahap awal pembangunan basis data pertanahan yang kemudian menjadi dataset dasar dalam pembangunan SIMTANAS, konsep SIP Multiguna mulai dijadikan arah pembangunan, namun belum ada rumusan yang dapat didokumentasikan. Seiring dengan pengembangan LOC mulai fase IA, IB, IIA, IIb, dan berubah ke KKP IIb, Larasita, sampai dengan KKPWeb, maka rumusan SIP Multiguna sudah mulai didokumentasikan.

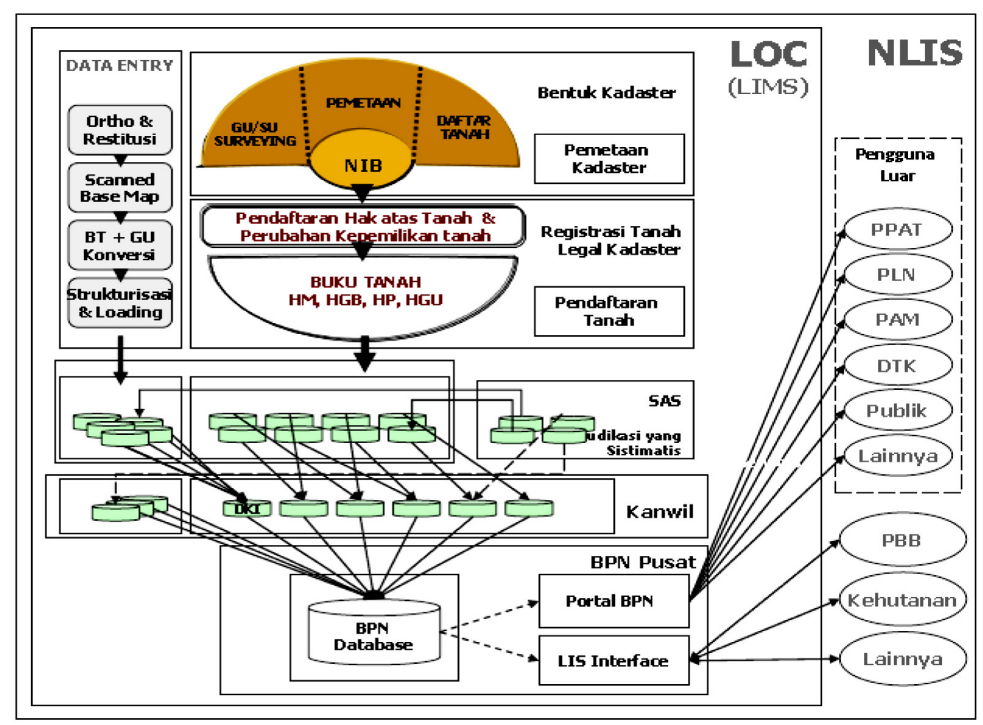

Gambar 2. Sistem Informasi Manajemen Pertanahan Nasional Multiguna Indonesia.

(Sumber : Pusdatin BPN RI, 2007)

Model sistem informasi pertanahan multiguna yang dikeluarkan BPN RI pada tahun 2007, sudah tidak relevan lagi dengan kondisi tata kelola pertanahan terkini dan semestinya harus direkayasa ulang (reengineering). Perubahan struktur organisasi dan nomenklatur BPN menjadi Kementerian Agraria dan Tata Ruang/Badan Pertanahan Nasional menyebabkan perubahan bisnis proses lembaga.

Rekayasa ulang SIMTANAS harus mengakomodasi fungi pengaturan dan pengendalian tata ruang yang diintegrasikan dalam tugas dan fungsi kementerian. Demikian pula perkembangan teknis data base pertanahan yang sekarang sudah tidak lagi dikelola secara terdistribusi pada server-server di kantor pertanahan dan kantor wilayah kementerian ATR/BPN, melainkan dikelola secara terpusat di Data Center Pusat Data dan Informasi (Pusdatin). 
Desain basis data pertanahan SIMTANAS eksisting dibangun dengan proses pendaftaran tanah yang diamanatkan dalam Pasal 19 UndangUndang Nomor 5 Tahun 196o tentang Peraturan Dasar Pokok-pokok Agraria (UUPA). Proses pendaftaran tanah ini berpedoman pada sistem administrasi pertanahan yang berlaku di Indonesia. Realita pelaksanaan pendaftaran tanah di Indonesia, yang tidak bisa dilakukan terhadap tanahtanah yang dikuasai oleh Kementerian Kehutanan dan Kawasan Pertambangan, disebabkan terbitnya Undang-Undang Nomor 5 Tahun 1967 tentang Pokok-pokok Kehutanan yang membatasi rezim legal administratif dari UUPA hanyalah 30\% dari luasan tanah secara nasional (Fourie dan Nasution 200o). Pemahaman ini terus berlanjut, dalam Undang-undang Nomor 41 Tahun 1999 tentang Pokok-pokok Kehutanan yang menggantikan UU Nomor 5 Tahun 1967. Kewenangan Kementerian ATR/BPN yang terbatas mengadministrasikan tanah-tanah di luar wilayah kehutanan dan pertambangan ini tidak sesuai dengan konsep dasar administrasi pertanahan yang seharusnya dapat dilaksanakan terhadap seluruh tanah di wilayah Negara Kesatuan Republik Indonesia. Hanya dengan melakukan administrasi pertanahan terhadap seluruh tanah di Indonesia tanpa kecuali, maka manajemen atas sumberdaya agraria di kawasan hutan maupun tambang akan menjadi lebih mudah dilaksanakan oleh kementerian yang menguasainya, maupun oleh pimpinan negara.

Terlaksananya proses pendaftaran tanah sebagai instrumen untuk pengadministrasian pertanahan, melahirkan kejelasan tata batas wilayah hutan dan pertambangan, demikian pula kewenangan pengaturannya juga akan menjadi lebih nyata. Kejelasan tata batas dan kewenangan penguasaan wilayah hutan dan tambang akan memperkecil kemungkinan terjadinya sengketa agraria. Penetapan batas serta hak dan kewenangan atas bidang tanah akan menjadi infrastruktur yang sangat penting guna pemanfaatan sumber-sumber agraria yang terkandung dalam bidang tanah oleh subyek hak atas tanah. Konsep administrasi pertanahan sebagai infrastruktur pemanfaatan sumberdaya agraria sendiri sesungguhnya merupakan konsep dasar administrasi pertanahan secara umum yang sudah diperkenalkan sejak tahun 1989. Ruang lingkup sistem adminitrasi pertanahan dapat diilustrasikan seperti berikut:

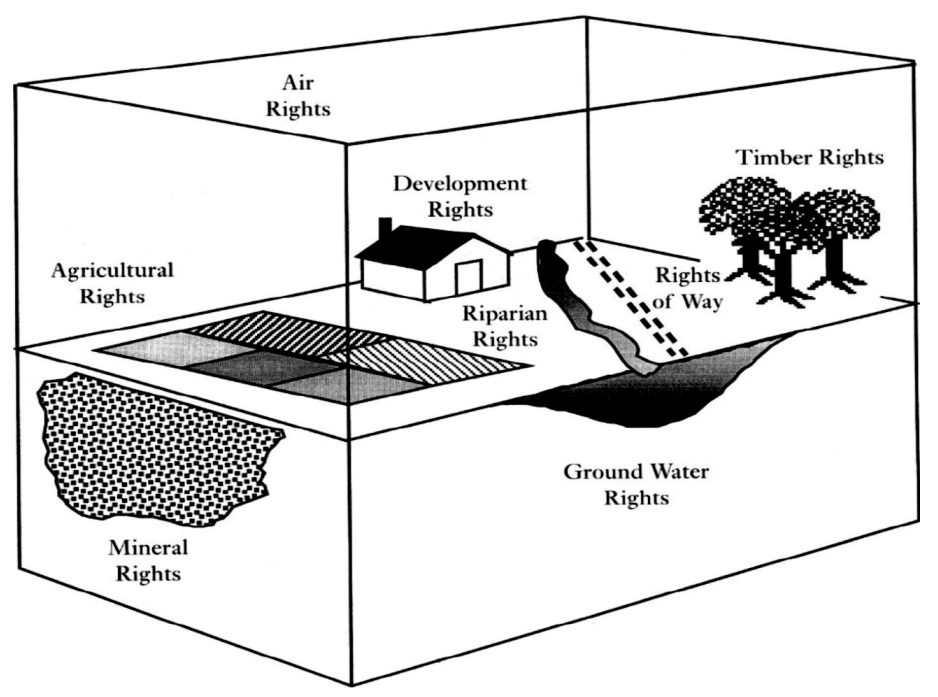

Gambar 3. The basic building block in any land administration system is the cadastral parcel. (Sumber: Land Administration, Dale dan McLaughin, 1999)

Pasal 19 UUPA, menegaskan bahwa pendaftaran tanah dilaksanakan untuk semua wilayah Indonesia. Pendaftaran Tanah terdiri dari proses pengukuran dan pemetaan bidang tanah, pembuktian dan pembukuan hak, dan pemberian sertipikat sebagai tanda bukti penguasaan dan atau pemilikan tanah.

Pada perkembagannya konsep sistem administrasi pertanahan tepat guna (Fit for Purpose Land Administration) menuntut pembangunan database pertanahan melalui pendaftaran tanah harus mencakup semua bidang tanah di seluruh Indonesia dilengkapi data penggunaan, pemanfaatan tanahnya, selain data penguasaan dan pemilikan tanah. 


\section{UUPA Pasal 19}

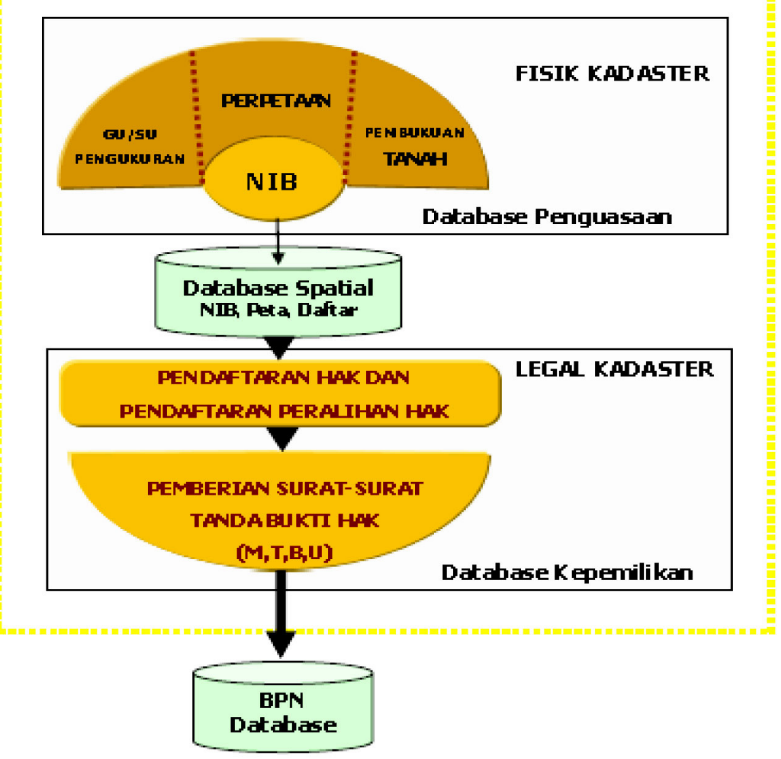

Gambar. 4. Pengumpulan Basis Data

Pertanahan berdasarkan Pasal i9 UUPA

Perubahan institusional untuk menyiapkan perubahan paradigma dalam manajemen pertanahan nasional diawali dengan serangkaian riset mengenai kondisi eksisting administrasi pertanahan pada tahun 1997. Salah satu dari rekomendasi risetriset ini menyatakan, agar negara juga mengaitkan pengaturan penggunaan tanah dalam tata laksana administrasi pertanahan sehingga basis data pertanahan tidak hanya didominasi oleh data penguasan dan pemilikan tanah saja namun juga mampu merekam data penggunaan dan pemanfaatan, termasuk pengaturannya.

Jika dalam proses pendaftaran tanah berdasar Peratutan Pemerintah Nomor 24 Tahun 1997 tentang Pendaftaran Tanah, pengumpulan datayuridis melalui Daftar Isian 201 hanya mencatat penggunaan tanah dari aspek penggunaan eksisting, maka pada masa sekarang harus dapat direkam pengaturan penggunaannya atau restriction-nya.

Perubahan model organisasional basis data pertanahan harus berubah dari basis data pertanahan yang bersumber dari kegiatan pendaftaran tanah, menuju basis data yang mengintegrasikan data pertanahan yang bersumber dari kegiatan inventarisasi data pemilikan, penguasaan, peng- gunaan, dan pemilikan tanah (IP4T), sensus pertanahan, dan pemetaaan partisipatif masayarakat. Basis data spasial tidak hanya dibatasi data spasial hasil plotting pengukuran terestris, namun juga harus mengakomodasi data spasial hasil pengukuran secara fotogrametris.

\section{Model fungsional}

Model fungsional digunakan untuk memodelkan fungi-fungsi dari sistem, ataupun perilaku sistem. Model fungsional dapat disajikan melalui Diagram Use Case. Merujuk pada konsep fit for purpose maka fungsi-fungsi sistem informasi pertanahan nasional harus mampu mendukung tata kelola semua sektor yang berhubungan dengan tanah. Pemodelan fungsi Sistem Informasi Pertanahan Nasional dilakukan dengan mengidentifikasi aktor yang berkaitan dengan tata kelola pertanahan. Fit for purpose untuk sektor yang berhubungan dengan tanah dapat dimodelkan dalam Diagram Use Case sebagai berikut:

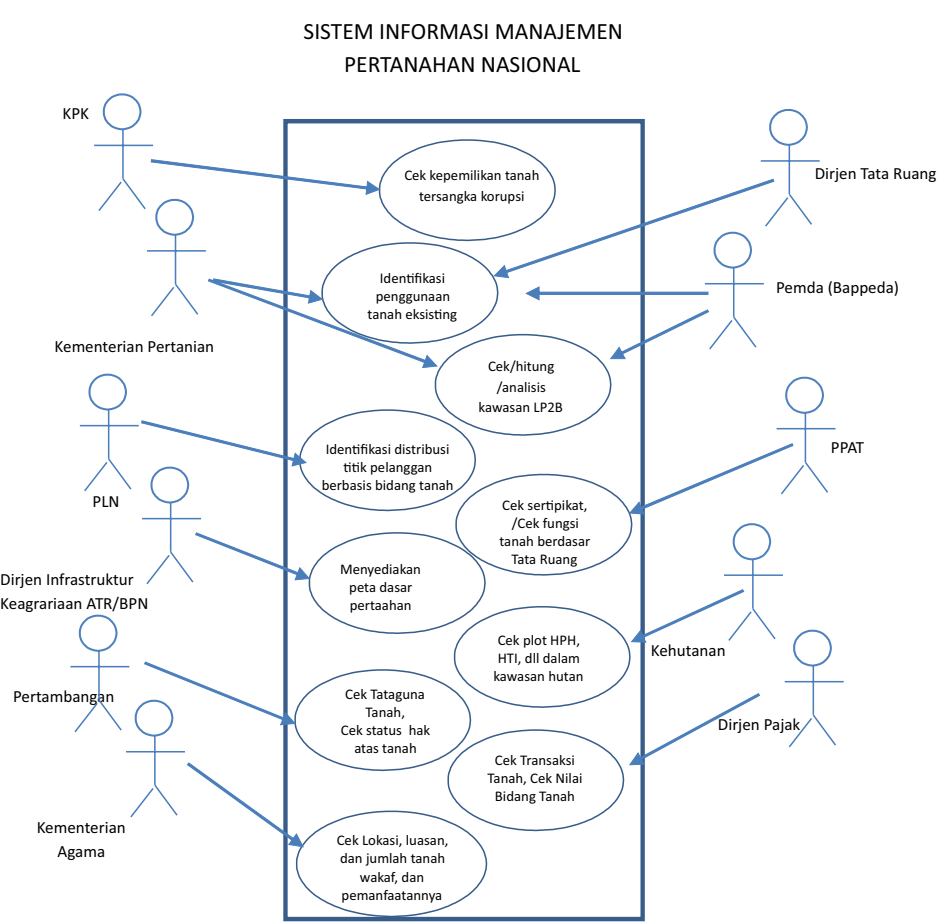

Gambar 5. Diagram Use Case SIMTANAS Mutiguna

\section{Model Statis}

Model statis memodelkan sebuah sistem dari sisi obyek-obyek yang terlibat dalam kinerja sebuah 
sistem. Pada tahun 1998, diperkenalkan konsep Core Cadastral Domain Model (CCDM), untuk memodelkan hubungan manusia dengan tanah. CCDM ini dikembangkan secara modular incremental. Artinya model data kadaster dibentuk dari modul-modul dasar, dan setiap modul dapat dikembangkan lebih lanjut sesuai dengan kebutuhan data kadastral yang ada pada suatu negara. Model dasar data cadastral terdiri dari 3 entitas yaitu Parcel, Person/Subject, dan RightsOrRestriction.

Entitas parcel, dikenal dengan nama RealEstate Object. Parcel atau RealEsate Object ini merupakan model dari bidang tanah. Entitas Person/Subject merupakan entitas yang mewakili subyek hak atas tanah, sementara RightOrRestriction memodelkan hubungan manusia dengan tanah yang salah satunya berwujud hak atas tanah. Derajat hubungan atau multisiplitas antara entitas Persil dan Person adalah $1 . .{ }^{*}: 1 . . . .{ }^{*}$ yang artinya setiap 1 orang sampai beberapa orang bisa memiliki hubungan dengan 1 sampai beberapa bidang.

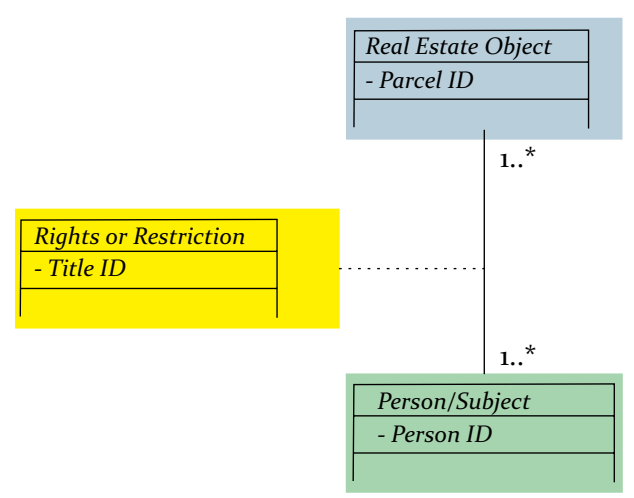

Gambar 6. Core Cadastral Domain Model. (Sumber : Lemmen et al., 2002)

CCDM mendefinisikan hubungan antara Person dengan Parcel bukan merupakan hubungan yang langsung, tetapi melaui RightorRestriction. CCDM terus dikembangkan dalam beberapa versi, dan terakhir adalah versi 1.o. dan menjadi rujukan dalam pengembangan model basis data kadastral untuk berbagai tujuan. Namun demikian dalam sejarah pengembangannya terdapat banyak ketidaksesuaian antara kelas dan atribut yang disediakan oleh CCDM dengan sistem kadaster di beberapa negara. Selanjutnya mulai tahun 2006, FIG mengembangkan Model Data Administrasi Pertanahan (Land Admnistration Domain Model) atau LADM. Standarisasi LADM dengan ISO 19152 ini diterima secara internasional pada tahun 2012. Model data domain kadastral, maupun model data domain administrasi pertanahan ini dimodelkan dengan diagram kelas atau diagram object. LADM terdiri dari 5 (lima) Pakcage yaitu:

1. Package Immovable dengan standar warna biru

2. Package Surveying dengan warna pink

3. Package Geometry and Topology dengan warna ungu/purple

4. Package Person dengan warna hijau

5. Package Legal/Administrative dengan warna kuning

Package Immovable, Surveying, serta Geometry and Topology merupakan pengembangan dari Kelas Parcel dalam CCDM, sementara kelas Person dan Legal/Administrative tetap dipertahankan.

LADM memodelkan entitas yang terlibat dalam administrasi pertanahan sesederhana mungkin dengan tujuan agar kompatibiitas dengan desain sistem informasi di berbagai negara yang biasanya menerapkan sistem kadaster yang berbeda-beda dapat dicapai. Hasil penelitian mengenai validasi LADM untuk menjadi model data dalam pembangunan SIMTANAS diteliti oleh Sucaya (2013), dan pada tahun 2014, LADM telah diadopsi sebagai model data aplikasi KKP Web dan Geo KKP Web. Namun demikian ada kelas, dan atribut yang memang belum dapat digunakan dalam konteks administrasi pertanahan di Indoensia.

\section{Model Dinamis}

Model dinamis sistem informasi manajemen pertanahan nasional merupakan model work flow dari penggunaan SIMTANAS mendukung pelaksanaan pendaftaran tanah, maupun pemanfaatan informasi untuk operasionalisasi kebijakan sektor lain yang berhubungan dengan tanah. Model dinamis ini dibuat dengan model diagram aktifitas (activity diagram) dan state chart diagram. 
Alur (workflow) penggunaan SIMTANAS untuk pendaftaran tanah merujuk pada Perkaban Nomor 1 Tahun 2010 tentang Standar Pelayanan Pertanahan dan Pengaturan Pertanahan (SPPP). Variasi layanan pertanahan berjumlah 99 layanan, dan masingmasing mempunyai alur yang berbeda, namun secara garis besar ada 2 jenis alur/work flow yaitu alur untuk layanan yang berakibat perubahan basis data spasial dan layanan yang tidak mengakibatkan perubahan spasial.

Diagram kedua alur layanan petanahan tersebut dapat dilihat pada Gambar 7 dan 8 sebagai berikut:
Kementerian ATR/Badan Pertanahan Nasional dapat menetapkan alur layanan untuk pemanfaatan data kadastral oleh sektor lain seperti Kehutanan, Pertambangan, Bappeda, Kementerian agama dan seterusnya sebagaimana telah digambarkan dalam Use Case Diagram SIMTANAS. Lebih lanjut layananlayanan spesifik seperti pendaftaran tanah pertama kali ataupun pemeliharaan data pendaftaran tanah dapat dimodelkan dengan Diagram Activity. Alur pendaftaran tanah pertama kali dimodelkan seperti
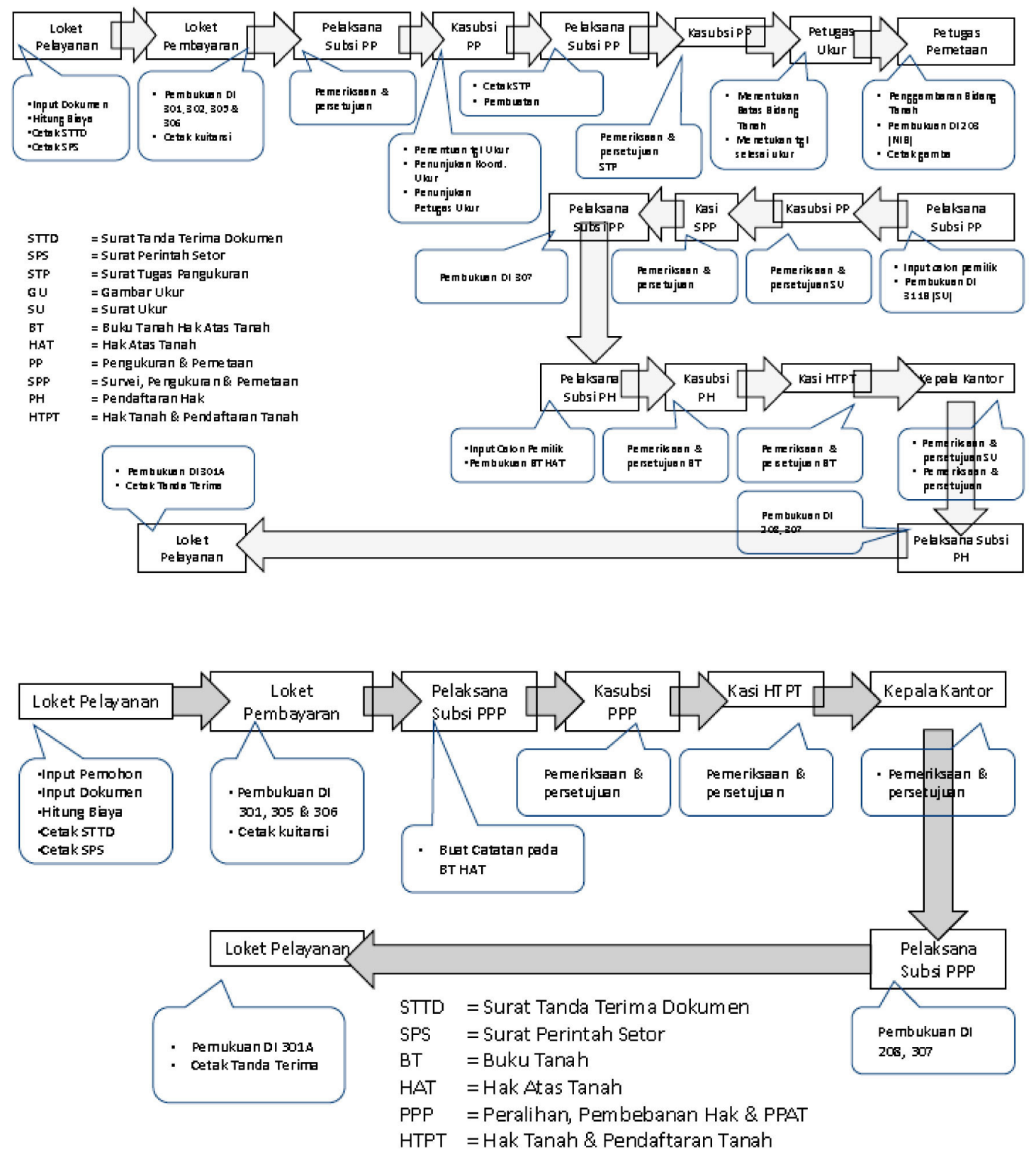

Gambar 8. Alur Layanan Pertanahan Tanpa Perubahan Basis Data Spasial 
berikut ini:

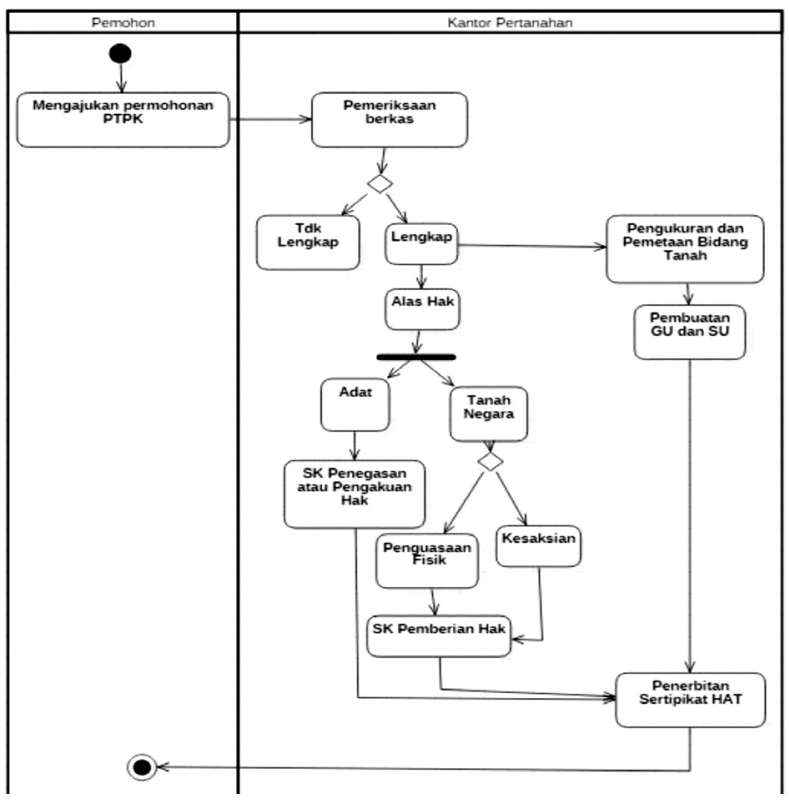

Gambar 9. Diagram Aktifitas Pendaftaran Tanah Pertama Kali

Proses peralihan hak atas tanah atau yang dikenal dengan pemeliharaan data pendaftaran tanah dimodelkan dalam diagram aktifitas sebagai berikut :

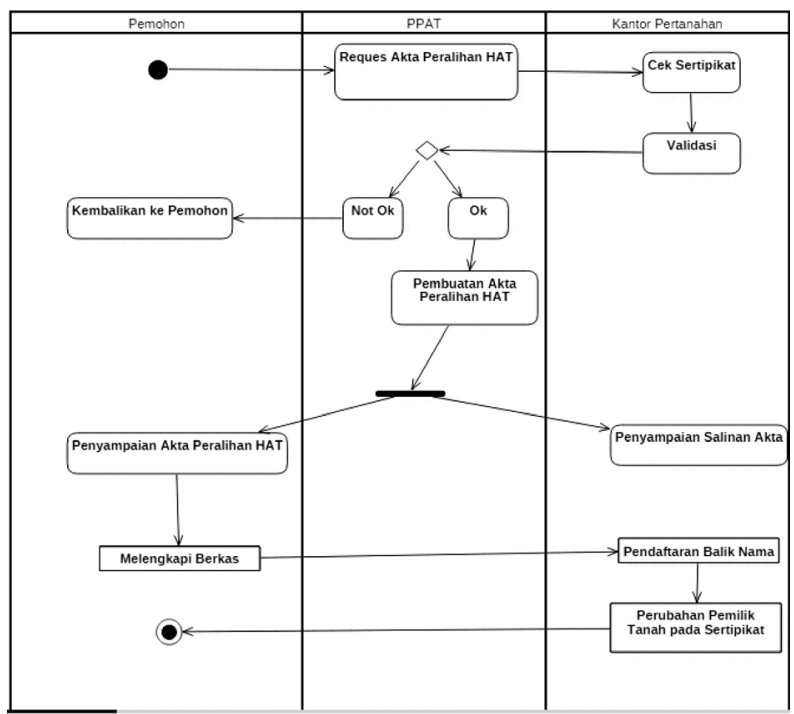

Gambar io. Alur Peralihan Hak Atas tanah

\section{Kesimpulan dan Penutup}

Perubahan ruang lingkup internal dan eksternal manajemen pertanahan memerlukan rekayasa ulang (reengineering) Sistem Informasi Pertanahan Nasional. Kerangka Sistem Informasi Manajemen
Pertanahan Nasional sudah tidak relevan lagi dengan perkembangan terkini kebijakan pertanahan yang memerlukan dukungan penyediaan data dan informasi pertanahan yang dapat digunakan oleh semua sektor yang terkait dengan tata kelola pertanahan.

Perkembangan nomenklatur dari yang semula hanya Badan Pertanahan Nasional yang kemudian dikuatkan kelembagaannya menjadi sebuah Kementerian ATR/BPN, harus menjadi rujukan bagi desain kerangka kelembagaan (institutional framework) dalam proses rekayasa ulang SIMTANAS ini. Rekayasa ulang SIMTANAS dapat menggunakan pendekatan unified modelling language, untuk memodelkan kerangka organisasional, fungsional, statis, dan dinamis, sehingga pemodelan SIMTANAS dapat benar-benar menggambarkan pendekatan mulai dari kebijakan (policy) sampai dengan implementasinya yang terwujud dalam operasionalisasi pendaftaran tanah dan administasi pertanahannya.

\section{Daftar Pustaka}

Booch, G, Rumbaugh, J, Jacobson, I 1999, The Unified Modelling Language, User Guide, Boston: Addition, 512 pp, Wesley.

Dale, P, and McLaughin, JD 1999, Land Administration, Oxford University Press.

Enemark, S 2004, 'Building Land Information Policies', dipresentasikan pada UN, FIG, PC IDEA Inter-regional Special Forum on The Building of Land Information Policies in the Americas Aguascalientes, Mexico 26-27 October 2004.

Enemark, S., Bell, KC, Lemmmen, C, McLaren, R 2014, Fit for Purpose Land Administration, The World Bank and the International Federation of Surveyors (FIG), Copenhagen, Denmark.

Fourie, C, Nasution, AA 2000, The Institutional Setting for Land Management Policy-Indonesia, National Development Planning Agency, Indonesia.

Kaufmann and Steudler, D 2001, 'Cadastre 2014 A Vision for Future Cadastral System', Inter- 
nasionale Federation of Surveyors (FIG), Denmark.

Lemmen, C and Oosterom, 'P.V. 2006 Version 1.o of The FIG Core Cadastral Domain Model', disajikan pada Konggres FIG XXIII, Munich, Jerman.

Rumbaugh, J, Jacobson, I, Booch, G 2004, The Unified Modelling Language, Reference Manual, Second Edition, Boston : Addition, Wesley.

Sholiq 2006, Pemodelan Sistem Informasi Berorientasi Obyek dengan UML, Graha Ilmu, Yogyakarta.

Steudler, D 2007, 'Cadastre 2014 Concepts', disajikan dalam Working Group on Modern Cadastre and Land Administration, Teheran, 2126 Juli 2007.
Sucaya, IKA 2009, 'Application and Validation the Land Administration Domain Model in a Real Life Situation (A case study in Indonesia), Thesis, International Institute For Geo-Information Science And Earth Observation, Enschede, The Netherlands.

Triono, Bambang 1989, Land Information Management, Puslitbang, Kemetrian Dalam Negeri, Jakarta.

Tuladhar, A 2002, 'Why Is UML for Cadastral System', Workshop on EUCOSTAction G9: Modelling Real PropertyTransaction COSTG9, Delft.

Twumasi BO 2002, 'Modelling Spatial Object Behaviours In Object Relational Geodatabase', Thesis, Magister Science of Geo-informatic, ITC, Netherland. 